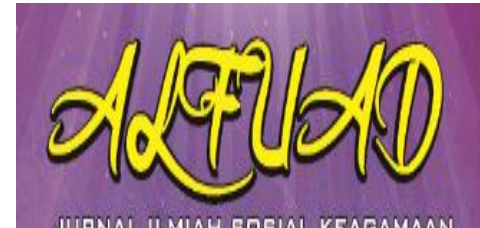

ALFUAD JOURNAL, 4 (2), 2020, (88-100)

(E-ISSN 2714-7606 P-ISSN 2614-4786 )

Available online at

http://ecampus.iainbatusangkar.ac.id/ojs/index.php/alfuad

\title{
MENGELOLA EMOSI MAHASISWA DALAM PEMBELAJARAN DARING MELALUI SUMBERDATA DIGITAL MASA PANDEMI COVID-19
}

\author{
Bachtiar Sinuraya \\ Universitas Negeri Malang, \\ Indonesia \\ E-mail: bachtiar.sinuraya @yahoo.com \\ Santi Virdaus Putri *) \\ Universitas Negeri Malang, \\ Indonesia \\ E-mail: SantiVp@gmail.com \\ Dwi Wahyuni \\ Universitas Negeri Padang, \\ Indonesia \\ E-mail: dwahyuni@gmail.com

\section{Desnawita} \\ Institut Aga ma Islam Negeri Batusangkar, \\ Indonesia \\ E-mail: desnawita @iainbatusangkar.ac.ic

\section{Tri Yuliani} \\ Institut Agama Islam Negeri Batusangkar, \\ Indonesia \\ E-mail: triyuliani@iainbatusangkar.ac.ic
}

\section{Meliana Sari}

Institut Agama Islam Negeri Batusangkar, Indonesia

E-mail: melianasari@iainbatusangkar.ac.ic

\section{Refika Mastanora}

Institut Aga ma Islam Negeri Batusangkar, Indonesia

E-mail:

refikamastanora@iainbatusangkar.ac.ic

*) Corresponding Author

Keywords: Emotion, Online, Data Sources, Digital

\section{PENDAHULUAN}

Kasus infeksi positif wabah virus corona (covid-19) di Indonesia mencapai 137.468 orag (Liputan 6, 15 Agustus 2020). Hal ini menggambarkan meningkat sebanyak 2.345 kasus dari masa

\begin{abstract}
This study intends to analyze and parse the management of student emotions in learning through digital sources during the Covid-19 pandemic. The family environment plays an active role in providing understanding and monitoring and paying attention to emotional states in learning. This research was conducted by analyzing literature from journals and effective data related to emotional management in online learning where the findings and new theories were described qualitatively. The results of these findings illustrate the need for the role of the tridarma of education, namely educators, students and families in managing emotions and the necessary facilities and infrastructure for students in online learning are more effective so that the education and learning process is carried out properly.
\end{abstract}

diumumkannya kasus covid-19 pada 2 maret 2020 lalu. Pandemic kovid menimbulkan berbagai dampak dan pengaruh bagi masyarakat, salah satu hadirnya kebijakan baru dalam bidang pendidikan dengan system kuliah daring 
(online) yang menjadi topic yang cendrung diperbincangkan dan menjadi evaluasi pelaksanaan pendidikan masa kementrian Nadiem Makarim saat ini.

Pemberlakuan kebijakan elearning/daring karena akan menimbulkan budaya baru yang hampir dilaksanakan oleh seluruh dunia dan lembaga pendidikan tidak terkecuali di Indonesia. Adanya surat edaran Mendikbud nomor 3 Tahun 2020 tentang Pencegahan Covid-19 pada Satuan Pendidikan, sebagai upaya pencegahan penyebaran corona virus Disease (Covid-19) mendukung berbagai macam kebijakan ini.

Ada sekitar 65 perguruan tinggi di Indonesia yang telah melaksanakan pembelajaran daring dalam mengantisipasi penyebaran Covid-19 (CNNIndonesia, 2020). Jamaluddin, D., Ratnasih, T., Gunawan, H., \& Paujiah, E. (2020) menyatakan bahwa pembelajaran daring memiliki kekuatan, tantangan dan hambatan tersendiri. Untuk mencegah penyebaran Covid-19, WHO memberikan himbauan untuk menghentikan acara-acara yang dapat menyebabkan massa berkerumun. Maka dari itu, pembelajaran tatap muka yang mengumpulkan banyak mahasiswa di dalam kelas ditinjau ulang pelaksanaanya. Perkuliahan harus diselenggarakan dengan skenario yang mampu mencegah berhubungan secara fisik antara mahasiswa dengan dosen maupun mahassiswa dengan mahasiswa (Firman, F., \& Rahayu, S., 2020). Menurut Milman (2015) penggunaan teknologi digital dapat memungkinkan mahasiswa dan dosen melaksanakan proses pembelajaran walaupun mereka ditempat yang berbeda. Bentuk perkuliahan yang dapat dijadikan solusi dalam masa pandemi covid-19 adalah pembelajaran daring. Menurut Moore, Dickson-Deane, \& Galyen (2011)

Penemuan penelitian pertama kali dilaksankan oleh masyarakat China sebagai Negara pertama yang terkonfirmasi mula munculnya pandemic covid-19 memperlihatkan adanya peningkatan keadaan emosi negative (kecemasan, depresi dan kemarahan) dan sensifitas terhadap resiko social, serta penurunan emosi positif dan kepuasan hidup setelah diumumkannya wabah covid-19 (Li, Wang, Xue, Zhao, and Zhu, 2020). Melalui Kementerian Pendidikan dan Kebudayaan Pemerintah telah melarang perguruan tinggi untuk melaksanakan perkuliahan tatap muka (konvensional) dan memerintahkan untuk menyelenggarakan perkuliahan atau pembelajaran secara daring (Surat Edaran Kemendikbud Dikti No. 1 tahun 2020). Perguruan tinggi dituntun untuk dapat menyelenggarakan pembelajaran secara daring atau on line (Firman, F., \& Rahayu, S., 2020) 
Sesungguhnya, budaya daring pada pendidikan tinggi dapat berpotensi sangat menegangkan bagi mahasiswa (Ramos \& Borte, 2012; Capdeferro \& Romero, 2012 dalam Hoang, 2015). Jika dipersepsi secara negatif, akan menimbulkan stres yang dapat memengaruhi kinerja akademik mahasiswa (Stewart et al., 1999, dalam Hoang, 2015) dan kepuasan hidup mereka secara keseluruhan (Chang, 1998).

Belum lagi situasi saat ini yang ternyata menjadikan masyarakat tetap beraktivitas di rumah lebih lama karena banyaknya daerah yang memperpanjang PSBB (Pembatasan Sosial Berskala Besar) menuntut mahasiswa lebih lama mengalami pembelajaran secara daring. Tidak mengherankan bila kondisi sekarang secara umum berpotensi mendorong hadirnya emosi negatif pada masyarakat sehingga menjadikan rentannya kondisi psikologis masyarakat. Hal ini perlu diperhatikan mengingat emosi negatif jangka panjang dapat mengurangi fungsi kekebalan tubuh manusia dan menghancurkan keseimbangan mekanisme fisiologis normal (Kiecolt-Glaser, McGuire, Robles, Glaser, 2002, dalam Li, Wang, Xue, Zhao, dan Zhu, 2020).

Keadaan pengelolaan emosi akan memperburuk kondisi kesehatan dan mengakibatkan bertambahnya kasus positif lainnya. Rangkaian masalah diatas menarik untuk diteliti bagaimana mengeloa emosi pada pembelajaran online/ elearning masa pandemic covid-19.

\section{METODE}

Penelitian ini merupakan penelitian dengan kajian pustaka menggunakan metode penelitian yang bersifat studi kepustakaan yang melihat masalahmasalah yang diteliti dan mencari sumber informasi berdasarkan literature, teori dan artikel yang dipublikasikan dalam berbagai jurnal ilmiah.

\section{HASIL DAN PEMBAHASAN}

Mengingat bahwa emosi ada dalam pengalaman manusia yang lebih luas dan komprehensif (Plutchick, 2003), mereka tidak dapat dianggap terpisah dari pengalaman lingkungan belajar (Brookfield, 2006; Lehman, 2006). Barubaru ini, ada peningkatan fokus pada emosi dan pembelajaran, yang umumnya diabaikan dalam penelitian pendidikan (Schutz \& Lanehart, 2002; Pekrun, Goetz, Titz, \& Perry, 2002; Dirkx, 2008; Värlander, 2008).

Selain itu, Brookfield (2006) dan Dirkx (2008) menyatakan bahwa emosi sering disalahartikan sebagai pencegah yang menghalangi pengajaran dan pembelajaran yang efektif. Sepertinya emosi memainkan peran yang jauh lebih dinamis dalam pembelajaran daripada sekadar menghambat pemikiran dan nalar rasional. Sebuah pemahaman tentang sifat 
emosi dalam konteks pembelajaran dapat membantu pembelajaran proses karena semua tindakan dan penalaran manusia "membutuhkan emosi fasilitasi yang sesuai jika tindakan sukses atau alasan sama sekali harus dicapai penekanan ditambahkan"(Barbalet, 2002, p. 1).

Lipman (2003) memberikan satu pengecualian untuk apa yang telah menjadi pendekatan emosi yang diabaikan. Dia secara eksplisit menulis tentang emosi sambil mendeskripsikan pembelajaran melalui komunitas inkuiri. Bagi Lipman, model komunitas inkuiri adalah "sepenuhnya sosial dan komunal; Sebuah metode untuk mengintegrasikan pengalaman emosi, tindakan mental, keterampilan berpikir, dan kekeliruan informal ke dalam pendekatan terpadu untuk peningkatan penalaran dan penilaian penekanan ditambahkan” (hlm. 18). Pengecualian lain untuk pengabaian adalah penerapan model yang sama di pembelajaran online oleh Garrison, Anderson, dan Archer (2000), yang mengidentifikasi ekspresi emosional sebagai bagian dari kehadiran online secara social.

Model ini menjelaskan praktik mengajar dan pembelajaran online mahasisiswa adalah komunitas kerangka penyelidikan (CoI) yang dikembangkan oleh Garrison, Anderson, dan Archer (2000). Model ini telah mendapat perhatian yang signifikan dan telah diteliti dengan baik (Akyol et al., 2009; Arbaugh et al., 2009). Ini menyediakan model konseptual berorientasi proses yang menginformasikan praktik instruksi online. Model memandang komunitas sebagai sesuatu yang muncul untuk mendukung pembelajaran online (Rovai, 2002; Thompson \& MacDonald, 2005; Shea, 2006) dalam hubungan antara tiga elemen: kehadiran sosial, kehadiran mengajar, dan kehadiran kognitif. Kehadiran sosial didefinisikan sebagai sejauh mana peserta didik merasa terhubung secara sosial dan emosional orang lain di lingkungan online.

$$
\text { Kehadiran kognitif }
$$
menggambarkan sejauh mana peserta didik mampu membangun dan menegaskan makna melalui refleksi dan wacana yang berkelanjutan. Itu elemen pengorganisasian pusat adalah kehadiran pengajaran: desain, fasilitasi, dan, yang paling penting, arah proses kognitif dan sosial untuk realisasi hasil pembelajaran yang bermakna secara pribadi dan bermanfaat secara pendidikan.

Kemungkinan peran diperluas karena kehadiran emosional, di luar pengaruh yang ditemukan dalam kehadiran sosial, adalah inti dari hal ini penelitian. Inovasi kreatif yang mengikuti perkembangan pembelajaran online memberikan keunikan tersendiri tempat untuk mempelajari kehadiran dan pembelajaran emosional. Seperti yang 
ditunjukkan oleh Anderson (2007), tujuh dari lima belas indikator ekspresi sosial adalah ekspresi emosi. Emosi diidentifikasi sebagai penting untuk penyesuaian mahasiswa terhadap peran pelajar online (Cleveland-Innes, Garrison \& Kinsel, 2007), perkembangan komunitas online (Perry \& Edwards, 2005), pemilihan format pembelajaran (Artino, 2010), dan persepsi, ekspresi, dan manajemen diri (Kang, Kim, \& Park, 2007). Conrad (2002), dalam studinya tentang emosi, secara gambling menceritakan gejolak perasaan, termasuk kecemasan, yang menyertai pengalaman dalam pembelajaran online.

\section{Pembelajaran daring dengan sumber pustaka daring}

E-Learning adalah sebuah proses pembelajaran yang berbasis elektronik. Salah satu media yang digunakan adalah jaringan komputer. Dengan dikembangkannya di jaringan komputer memungkinkan untuk dikembangkan dalam bentuk berbasis web, sehingga kemudian dikembangkan ke jaringan komputer yang lebih luas yaitu internet. Penyajian e-learning berbasis web ini bisa menjadi lebih interaktif. Sistem e-learning ini tidak memiliki batasan akses, inilah yang memungkinkan perkuliahan bisa dilakukan lebih banyak waktu.
Manfaat E-learning adalah: (1) Fleksibel. E-learning memberi fleksibilitas dalam memilih waktu dan tempat untuk mengakses perjalanan. (2) Belajar Mandiri. E-learning memberi kesempatan bagi pembelajar secara mandiri memegang kendali atas keberhasilan belajar. (3) Efisiensi Biaya. E-learning memberi efisiensi biaya bagi administrasi penyelenggara, efisiensi penyediaan sarana dan fasilitas fisik untuk belajar dan efisiensi biaya bagi pembelajar adalah biaya transportasi dan akomodasi.

Manfaat E-learning menurut Pranoto, dkk (2009:309) adalah: (1) Penggunaan E-learning untuk menunjang pelaksanaan proses belajar dapat meningkatkan daya serap mahasiswa atas materi yang diajarkan. (2) Meningkatkan partisipasi aktif dari mahasiswa. (3) Meningkatkan partisipasi aktif dari mahasiswa. (4) Meningkatkan kemampuan belajar mandiri mahasiswa. Meningkatkan kualitas materi pendidik dan pelatihan. (6) Meningkatkan kemampuan menampilkan informasi dengan perangkat teknologi informasi, dimana dengan perangkat biasa sulit dilakukan. (Riadi, 2014)

Kelebihan E-Learning memiliki kelebihan sebagai berikut: (1) Tersedianya fasilitas e-moderating dimana pengajar dan siswa dapat berkomunikasi secara mudah melalui fasilitas internet secara reguler 
atau kapan saja kegiatan berkomunikasi itu dilakukan tanpa dibatasi oleh jarak, tempat, dan waktu. (2) Pengajar dan siswa dapat menggunakan bahan ajar yang terstruktur dan terjadwal melalui internet. (3) Siswa dapat belajar (me-review) bahan ajar setiap saat dan dimana saja apabila diperlukan mengingat bahan ajar tersimpan di komputer. (4) Bila siswa memerlukan tambahan informasi yang berkaitan dengan bahan yang dipelajarinya, ia dapat melakukan akses di internet. (5) Baik pengajar maupun siswa dapat melakukan diskusi melalui internet yang dapat diikuti dengan jumlah peserta yang banyak. (6) Berubahnya peran siswa dari yang pasif menjadi aktif. (7) Relatif lebih efisien. Misalnya bagi mereka yang tinggal jauh dari Perguruan Tinggi atau sekolah konvensional dapat mengaksesnya

Kekurangan E-Learning juga tidak terlepas dari berbagai kekurangan, yaitu sebagai berikut: (1) Kurangnya interaksi antara pengajar dan mahasiswa atau bahkan antara mahasiswa itu sendiri, bisa memperlambat terbentuknya values dalam proses belajar mengajar.

Kecenderungan mengabaikan aspek akademik atau aspek sosial dan sebaliknya mendorong aspek bisnis atau komersial. (3) Proses belajar dan mengajarnya cenderung ke arah pelatihan dari pada pendidikan. (4) Berubahnya peran guru dari yang semula menguasai teknik pembelajaran konvensional, kini dituntut untuk menguasai teknik pembelajaran dengan menggunakan ICT (Information Communication Technology).

Mahasiswa yang tidak mempunyai motivasi belajar yang tinggi cenderung gagal. (6) Tidak semua tempat tersedia fasilitas internet (berkaitan dengan masalah tersedianya listrik, telepon, dan komputer). (Taufik.net, 2010)

\section{Hubungan Pembelajaran dengan keadaan emosi}

Hubungan antara emosi dan proses pembelajaran, pengajaran proses dan mahasiswa. Proses Pembelajaran Secara khusus, ini melibatkan tiga proses kognitif: perhatian, memori dan penalaran, yang berkaitan dengan masing-masing proses kemampuan kognitif mahasiswa tergantung pada emosi mereka (Frasson, 2010). Menurut mereka, emosi bisa digunakan dalam pembelajaran konten untuk meningkatkan perhatian mahasiswa dan meningkatkan kemampuan, memori dan penalaran mereka. Dengan cara ini, hubungan antara objek atau ide lebih mudah dilakukan dan mendorong efisiensi dan ketelitian dalam pengambilan keputusan dan masalah pemecahan (Isen, 2000). Secara umum, emosi ini mengarah pada proses yang lebih kreatif dari pemikiran yang fleksibel dan divergen, sementara emosi negative menyebabkan 
pemikiran yang lebih linier, konvergen dan sekuensial (Pekrum, 2005).

Proses Mengajar. Peran Tutor (kompetensi dan keterampilan baru): harus disiapkan untuk menghasilkan dialog yang efektif dengan peserta dan di antara peserta. Jadi itu mendukung pembelajaran aktif, membangun pengetahuan kooperatif/kolaboratif, guru tahu bagaimana mengidentifikasi perasaan dan emosi, kontrol dan menyediakan model ekspresi yang sesuai. Terutama ketika ini berhubungan dengan emosi negatif, yang seringkali lebih sulit berkomunikasi dengan cara yang hormat. Kecerdasan emosional guru berpengaruh signifikan terhadap terciptanya kehidupan yang sehat iklim emosional di kelas, tempat mereka mengelolanya dengan cara yang benar emosi mereka dan di mana emosi bisa berada diekspresikan tanpa takut dihakimi atau diejek (Ibarrola, 2000).

Mahasiswa. Studi tentang perlawanan, sikap dan emosi tentang Penggunaan teknologi sebagai sumber belajar terbukti sangat diperlukan untuk mengurangi angka putus sekolah dan kegagalan itu model eLearning saat ini menunjukkan (Cabrera, 2006).

\section{Mengenali psikologis mahasiswa}

Psikososial dan kesehatan mental anak selama pandemi COVID-19 dengan memahami kebutuhan emosional anak dengan cara (Unicef, 2020): (1) Anak-anak mungkin mengungkapkan tekanan psikologis (kecemasan, kesedihan) dengan bertindak dengan cara yang berbeda setiap anak berperilaku berbeda. Beberapa mungkin menjadi diam sementara yang lain mungkin merasakan dan mengungkapkan kemarahan dan hiperaktif. Pengasuh perlu bersabar dengan anak-anak dan memahami emosi mereka. (2) Semua emosi adalah emosi yang valid, dan sebagai pengasuh kita perlu memahaminya dengan empati. (3) Terkadang terlibat dalam aktivitas interaktif yang kreatif, seperti bermain dan menggambar dapat memfasilitasi ini proses. Bantu anak-anak menemukan cara positif untuk mengungkapkan perasaan yang mengganggu seperti kemarahan, ketakutan, dan kesedihan. (4) Jaga rutinitas dan jadwal rutin sebanyak mungkin. (5) Jika anak menyaksikan kekerasan di rumah, atau jika mereka menjadi sasaran kekerasan, itu menyebabkan trauma dan kesusahan dan dapat menyebabkan perilaku yang mengganggu. (6) Jelaskan kepada mereka bahwa tidak ada yang boleh distigmatisasi atau diberi isyarat karena mengidap penyakit. (7) Hindari menonton, membaca, mendengarkan atau mendiskusikan terlalu banyak berita tentang COVID-19 dan bujuklah anakanak untuk mengalihkan perhatian mereka ke topik lain juga. 
Membantu Anak-anak menghadapi peristiwa stress dengan langkah berikut:

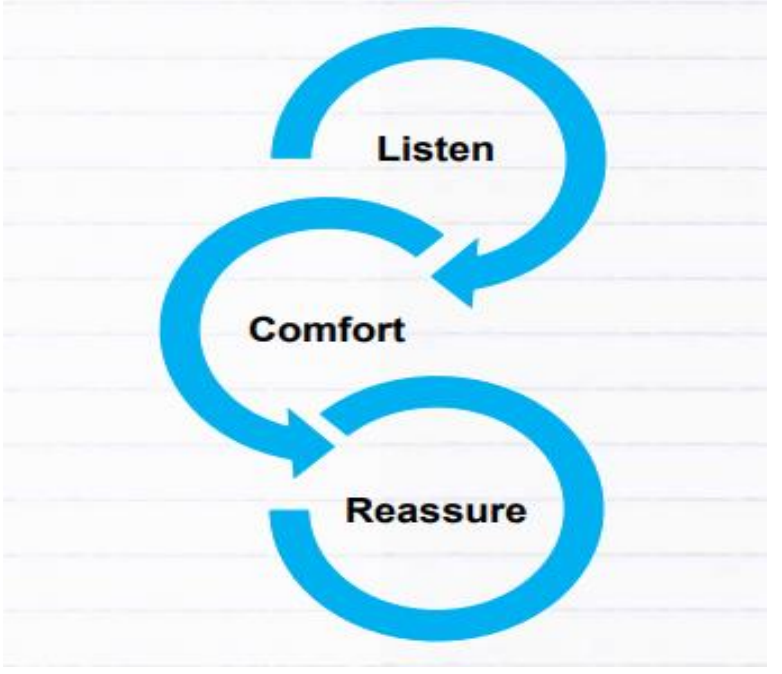

Gambar. 1. Kerangka pemikiran pemahaman membantu anak menghadapi

peristiwa stress dan emosi tidak stabil

Listen: Beri anak-anak kesempatan untuk berbicara tentang apa yang mereka rasakan. Dorong mereka untuk berbagi keprihatinan dan bertanya. Comfort: Gunakan alat sederhana untuk kenyamanan dan ketenangan anak-anak, misalnya bercerita, bernyanyi bersama mereka dan bermain permainan. Puji mereka seringkali untuk kekuatan mereka, seperti menunjukkan keberanian, kasih sayang dan kegunaan. Reassure: anak-anak bahwa Anda memang benar bersiap untuk menjaganya tetap aman. Menyediakan mereka dengan informasi yang benar melalui sumber yang valid.

\section{Metode pembelajaran daring}

Pada metode kuliah daring di masa pandemi Covid-19 ini ternyata terdapat 4 (empat) kelompok dosen yang menerapkan metode daring (Tanan, 2020).

\section{Kelompok 1}

Dosen di kelompok ini melakukan kuliah daring sebatas mengirim bahan ajar melalui media sosial yang populer seperti Whatsapp (WA) atau melalui email. Sebagai akibatnya pengalaman kuliah yang sangat beragam hanya tergantikan oleh komunikasi melalui WA atau email. Ini tentunya dapat membuat mahasiswa merasa bosan dan sangat merasakan kehilangan suasana kuliah seperti yang mereka nikmati sebelumnya.

\section{Kelompok 2}

Dosen di kelompok yang kedua ini melakukan kuliah melalui platform seperti Moodle, Edmodo, Google Classroom, Schoology atau platform lain yang sejenis. Dosen di level 2 paham tentang LMS (Learning Management System) dan dapat memanfaatkan fitur-fitur yang ada misalnya untuk melakukan kuis. Namun demikian komunikasinya yang terjadi masih sebatas bertukar catatan saja dan tidak ada interaksi yang langsung secara verbal, atau secara verbal dan visual sekaligus misalnya melalui video call.

Mahasiswa didik mungkin akan merasakan sebuah pengalaman baru dan berbeda untuk beberapa saat namun dalam jangka panjang bila hanya seperti ini saja 
maka mahasiswa akan kehilangan suasana sosial dalam belajar.

\section{Kelompok 3}

Dosen di kelompok ini mengelola kuliah melalui platform LMS (Learning Management System) dan juga mengkurasi bahan ajar yang terdapat di internet serta secara sengaja menciptakan interaksi langsung yang terjadwal dengan peserta didik secara sinkron. Di kelompok ini dosen dengan mahasiswa berkomunikasi dan berinteraksi langsung dengan mendengar suara, atau suara dan gambar walaupun itu dilakukan melalui teknologi. Untuk para dosen yang masuk di kelompok 3 ini interaksi sosial menjadi agenda dari rencana pembelajaran.

\section{Kelompok 4}

Dosen di kelompok 4 ini melakukan pembelajaran daring seperti kelompok 3 namun mereka menambahkannya dengan instruksi belajar yang lebih bervariasi termasuk menjadikan dirinya sendiri sebagai sumber belajar dengan cara membagikan rekaman suara atau video yang diproduksi sendiri untuk keperluan pembelajaran daring.

Dosen dapat menghasilkan instruksi-instruksi yang memandu mahasiswa untuk bisa melakukan collaborative learning dan experiential learning secara mandiri di tempat masing- masing. Tentunya banyak faktor yang menjadikan seorang dosen berada dalam kategori kelompok tertentu. Penguasaan dosen pada teknologi, fasilitas teknologi yang dimiliki serta kreatifitas para dosen menjadi kunci. Apabila boleh memilih, barangkali baik mahasiswa dan dosen lebih memilih kuliah tatap muka daripada daring karena faktor kebiasaan serta adanya masalah pada jaringan internet yang terkait juga dengan biaya kuota yang dikeluarkan.

Hal ini bisa dipahami mengingat penggunaan platform yang memungkinkan penggunaan audio-visual secara bersamaan dapat menyed ot kuota internet dengan lebih cepat yang artinya menjadikan biaya yang lebih tinggi. Selain itu jaringan yang bermasalah bisa terjadi sehingga proses kuliah tidak begitu efektif untuk tanyajawab serta dalam hal menerangkan materi.

Mahasiswa mengeluhkan waktu yang terbatas karena para dosen lebih banyak memberikan tugas/quiz. Para dosen yang harus bekerja di rumah ternyata mengalami kesulitan karena di rumah pun banyak hal yang membuat mereka terdistraksi karena menumpuknya pekerjaan lain. Hilangnya kebersamaan dengan teman-teman dan menghabiskan waktu santai bersama sebayanya menjadi hal yang dikeluhkan mahasiswa. 
Strategi mengurangi emosi negative masa pandemic covid-19

Strategi mengurangi emosi negatif karena pandemi covid-19:

\section{Mahasiswa}

Memulai awal hari dengan kegiatan positif seperti berolahraga, berjemur, sarapan, dan mandi. Dengan tujuan agar lebih semangat menjalani hari.

Membuat "list to do" kegiatan harian. Daftar ini bertujuan agar lebih jelas dan teratur dalam mengerjakan kegiatan di satu hari penuh dan jangan menunda nunda mengerjakan kegiatan/tugas.erjakan tugas secara langsung tanpa ditunda.

Berinteraksilah Jangan ragu untuk berkomunikasi dengan teman. Berkomunikasi dengan teman melalui telepon/video call membuat kita menjadi lebih semangat mengerjakan tugas karena lebih mudah memahami penjelasan ketika mendengar suara teman secara langsung walaupun dibantu oleh media media telepon/video call.

Menyelingi aktivitas di depan laptop dengan menengok ke luar jendela, berjalan di halaman Bersyukur.

Dosen

Pahami Keterbatasan: Dosen perlu memahami kondisi yang dihadapi mahasiswa saat merancang tugas, termasuk perangkat untuk menunjang pembelajaran daring yang dimiliki mahasiswa. Metode Variatif: Pilih metode pengajaran yang variatif agar mahasiswa tidak bosan dan lebih aktif dalam proses perkuliahan berlangsung, misalnya sesekali menggunakan kuliah dalam aplikasi whatsapp group atau zoom dan di waktu lain mendorong mahasiswa mengikuti seminar gratis online dengan topik yang sesuai. Deadline yang Realistis: untuk mencapai sasaran belajar yang tepat, upayakan pemberian tugas diberikan tenggat waktu yang realistis, sesuai dengan kesulitan tugasnya. Komunikasi dengan Mahasiswa: Jalin komunikasi dengan mahasiswa di awal pembelajaran dan pemberian tugas. Pastikan mahasiswa paham dan meminta masukan kepada mahasiswa terkait platform apa yang mudah dijangkau oleh mahasiswa sehingga, mahasiswa merasa dilibatkan dan termotivasi untuk menyelesaikan dengan baik. Pilih tugas yang penting: sebaiknya dosen memilih tugas yang penting saja bagi mahasiswa. Hal itu juga akan mengurangi beban bagi mahasiswa dan dosen yang mengoreksi. Terus berinteraksi dengan kolega di tempat kerja

\section{Peran pemerintah dan keluarga dalam} ketersediaan sarana dan prasarana

Ketentuan pedagogis dan pendidikan terkait pada materi tentang 
menjaga keselamatan peserta didik dan guru/ dosen di sisi kesehatan mental harus diperkenalkan pada kurikulum darurat: tenaga pengajar berpandangan bahwa ini harus menjadi prioritas dalam cara sistem pendidikan dalam menangani situasi saat ini, yang menanggung kesulitan yang signifikan bagi kesejahteraan semua pelaksanaan pendidikan.

Kegiatan belajar-mengajar sekarang telah menjadi faktor stres: evaluasi baru metode dan ketidakpastian, peralatan langka untuk mengikuti kursus pendidikan dengan benar, kurangnya digital, kemampuan kompetensi, dll. semuanya merupakan faktor pemicu stres baru. Terlebih lagi bagi para tenaga pendidik dan pelatih, yang juga harus menanggung beban keseluruhan pada sistem pendidikan dan pelatihan di pundak mereka. Seringkali mereka dibiarkan sendiri, menghadapi pelayanan, arahan yang mendorong mereka untuk mengakhiri program, mengajar dalam konteks yang tidak normal dan kurang alat dan sumber daya yang memadai di ekosistem yang tidak bersahabat.

\section{KESIMPULAN}

Pembelajaran daring membutuhkan pengelolaan emosi akan menentukan hasil belajar. Preferensi belajar dan kepribadian meningkatkan pola belajar daring. Pembelajaran daring mampu menjadikan masyarakat tetap memiliki kompetensi ketika keadaan tidak memungkinkan untuk belajar. Belajar daring sangat membutuhkan perhatian dari segenap lini mulai dari sekolah, tenaga pengajar, dan yang terpenting adalah ketersediaan sarana dan prasarana dalam mendukung pembelajaran. Adanya koordinasi yang efektif antara tenaga pendidik dan kependidikan bersinergi dengan baik sehingga keadaan emosi karena ketiadaan sarana pembelajaran dapat teratasi dengan baik pula.

\section{DAFTAR PUSTAKA}

Akyol, Z., Arbaugh, B., Cleveland-Innes, M., Garrison, R., Ice, P., Richardson, J., \& Swan, K. (2009). A response to the review of the community of inquiry framework. Canadian Journal of Distance Education, 23(2), 123-136.

Anderson, T. (2007). Social and cognitive presence in virtual learning environments. Keynote lecture, CHAIS Conference, The Open University of Israel. Retrieved from http://www.slideshare.net/terrya/so cial-and-cognitive-presence-invirtuallearning-environments

Artino, A. R. Jr. (2010). Online or face-toface learning? Exploring the personal factors that predict students' choice of instructional format. Internet and Higher Education, 13(4), 272-276.

Barbalet, J. (2002). Introduction: Why emotions are crucial. In J. Barbalet (Ed.), Emotions and sociology (pp. 1-19). Oxford: Blackwell

Barbalet, J. (2002). Introduction: Why emotions are crucial. In J. Barbalet (Ed.), Emotions and sociology (pp. 1-19). Oxford: Blackwell 
Brookfield, S. D. (2006). The skillful teacher: On technique, trust and responsiveness in the classroom. San Francisco: Jossey-Bass

Cabrera, L., Bethencourt, J.T., Gonzlez, M. lvarez, P. (2006). Un estudio transversal retrospectivo sobre prolongacin y abandono de estudios universitarios. Revista Electrnica de Investigacin y Evaluacin Educativa, 12(1), 129-149.

Cleveland-Innes, M., \& Campbell, P. (2006, November). Understanding emotional presence in an online community of inquiry. Paper presented at the 12th Annual SLOAN-C ALN Conference, Orlando, Florida

Cleveland-Innes, M., Garrison, R., \& Kinsel, E. (2007). Role adjustment for learners in an online community of inquiry: Identifying the needs of novice online learners. International Journal of Web-based Learning and Teaching Technologies, 2(1), 1-16.

CNNIndonesia. (n.d.-a). 4 Aplikasi Video Conference yang Irit dan Boros Data. Retrieved from https://www.cnnind onesia.com/tek nologi/20200330191529-185488422/4-aplikasi- videoconference-yang-irit-d an-borosdata

CNNIndonesia. (n.d.-b). 65 Kampus Kuliah dari Rumah, Sultan Yogya Ragukan Efektivitas. Retrieved from

https://www.cnnind onesia.com/nasi onal/20200316110707-20-

483756/65- kampus-kuliah-d arirumah-sultan-yogya-ragukanefektivitas

Conrad, D. (2002). Engagement, excitement, anxiety, and fear: Learners' experience of starting an online course. American Journal of Distance Education, 16(4), 205226.

Dirkx, J. M. (2008). The meaning and role of emotions in adult learning. New
Directions for Adult and Continuing Education, 120, 7-18.

Enriquez, M. A. S. (2014). Students' Perceptions on the Effectiveness of the Use of Edmodo as a Supplementary Tool for Learning. DLSU Research Congress. https://doi.org/10.1017/CBO97811 07415324.004

Firman, F., \& Rahayu, S. (2020). Pembelajaran Online di Tengah Pandemi Covid19. Indonesian Journal of Educational Science (IJES), 2(2), 81-89.

Frasson, C. Chalfoun, P. (2010). Managing Learners Affective States in Intelligent Tutoring Systems. In Nkambou, R., Mizoguchi, R. Bourdeau, J. (Eds.) Advances in Intelligent Tutoring Systems (pp. 339358). Springer-Verlag, BerlinHeidelberg.

Garrison, D. R., \& Cleveland-Innes, M. (2005). in Online Learning: Interaction Is Not Enough.

Garrison, D. R., Anderson, T., \& Archer, W. (2000). Critical inquiry in a text-based environment: Computer conferencing in higher education. The Internet and Higher Education, 2, 1-19.

Gikas, J., \& Grant, M. M. (2013). Mobile computing devices in higher education: Student perspectives on learning with cellphones, smartphones \& social media. Internet and Higher Education. https://doi.org/10.1016/jiheduc.201 3.06 .002

Ibarrola, B. (2000). Leducaci emocional. Infncia, 116, 5-8

Isen, A.M. (2000). Positive Affect and Decision Making(ed) Handbook of Emotions. Guilford, New York Handbook of Emotions (2nd ed., pp. 417-435). New York: Guilford.

Kang, M., Kim, S., \& Park, S. (2007). Developing emotional presence scale for measuring students' involvement during e-Learning 
process. In C. Montgomerie \& $\mathrm{J}$. Seale (Eds.), Proceeding s of World Conference on Educational Multimedia, Hypermedia and Telecommunications 2007 (pp. 2829-2832). Chesapeake, VA: AACE.

Lehman, R. (2006). The role of emotion in creating instructor and learner presence in the distance education experience. Journal of Cognitive Affective Learning, 2(2), 12-26

Lipman, M. (1991). Thinking in education. Cambridge: Cambridge University Press

Pekrun, R (2005). Progress and open problems in educational emotion research. Learning and Instruction, 15(5), 497-506

Pekrun, R., Goetz, T., Titz, W., \& Perry, R. P. (2002). Academic emotions in students' self regulated learning and achievement: A program of qualitative and quantitative research. Educational Psychologist, 37(2), 91-105.

Perry, B., \& Edwards, M. (2005). Exemplary online educators: Creating a community of inquiry. Turkish Online Journal of Distance Education, 6(2), 46-54. Retrieved from http://tojde.anadolu.edu.tr/tojde18/i ndex.htm

Plutchick, R. (2003). Emotions and life. Washington, DC.: American Psychological Association.

Rovai, A. P. (2002). Sense of community, perceived cognitive learning, and persistence in asynchronous learning networks. The Internet and Higher Education, 5(4), 319-332.

Sadikin, A., Johari, A., \& Suryani, L. (2020). Pengembangan multimedia interaktif biologi berbasis website dalam menghadapi revolusi industri 4.0. Edubiotik: Jurnal Pendidikan, Biologi Dan Terapan, 5(01), 18-28. https://doi.org/10.33503/ebio.v5i01 .644
Schutz, P. A., \& Lanehart, S. J. (2002). Introduction: Emotions in education. Educational Psychologist, 37, 67-68.

Shea, P. (2006). A study of students' sense of learning community in online environments. Journal of Asynchronous Learning Networks, 10(1). Retrieved from http://sloanconsortium.org/jaln/v10 n1/study-students\%E2\%80\%99sense-learning-community-onlineenvironments

Thomas. 2020. Liputan 6: Update Corona Covid-19 di Indonesia 15 Agustus 2020, Melonjak 2.345 Kasus. Diakses pada tanggal 16 Agustus 2020 pukul 08.30 wib.

Thompson, T. L., \& MacDonald, C. J. (2005). Community building, emergent design and expecting the unexpected: Creating a quality eLearning experience. The Internet and Higher Education, 8(3), 233-249.

Unicef. 2020. Psychosocial Support for Children during Covid-19: A Manual for Parents and caregivers. 1-81.

Värlander, S. (2008). The role of students' emotions in formal feedback situations. Teaching in Higher Education, 13(2), 145-156

Zhang, D., Zhao, J. L., Zhou, L., \& Nunamaker, J. F. (2004). Can elearning replace classroom learning? Communications of the ACM.

https://doi.org/10.1145/986213.986 216

Zheng, F., Liao, C., Fan, Q. H., Chen, H. B., Zhao, X. G., Xie, Z. G., ... \& Lu, W. (2020). Clinical characteristics of children with coronavirus disease 2019 in Hubei, China. Current medical science, 16. 